\title{
Dochází v ČR ke konvergenci hodnotového profilu lidí žjících $v$ manželství a nesezdaném soužití?
}

\author{
Have the Values of Individuals in Marriage and Cohabitation \\ Been Converging in the Czech Republic?
}

Martin Kreidl

\begin{abstract}
This article compares values and attitudes of individuals in two most common forms of partnership - marriage and cohabitation. First, it ascertains if different value profiles indeed exist. Second, it confirms that these do not merely reflect the different composition of these forms of partnership in terms of education, age, and number of children of married/cohabiting individuals. Finally, it examines whether a convergence in values and attitudes has been taking place recently. The analysis utilizes Czech data from the three waves of the European Value Study, which took place in the Czech Republic in 1991, 1999, and 2008. It turns out that differences exist, do not converge in time, and are not explained by compositional effects. This might suggest that these differences are not merely resulting from self-selection of different individuals into cohabitation as compared to marriage.
\end{abstract}

KEY WORDS cohabitation, marriage, social change, values

\section{1. Úvod: hodnoty, manželství, kohabitace}

S rostoucím výskytem nesezdaného soužití (kohabitace) v moderních společnostech rostl i zájem sociologie, demografie i dalších disciplín o tento populační fenomén (srov. Seltzer 2000, Smock 2000). Protože je kohabitace pro některé jedince náhradou manželství (srov. Thornton, Axinn a Xie 2007) a je často místem pro plození, rození a výchovu dětí, je někdy nazývána „neformálním“ případně „faktickým“ manželstvím (srov. Clarkberg, Stolzenberg a Waite 1995; Landale a Fennelly 1992). Tato pojmenování, která naznačují, že mezi sezdaným a nesezdaným soužitím není jiných než právních rozdílů, zároveň vymezují jedno velké téma rodinné demografie posledních dekád. Téměř nekončící řada badatelů srovnávala formální a neformální partnerské svazky, aby identifikovala jejich podobnosti a rozdíly.

Množství srovnávaných dimenzí je téměř stejně nepřeberné jako množství badatelů, kteří se nejrůznějším srovnáním věnovali a věnují. Namátkou vyberme ze světových

Sociální studia. Fakulta sociálních studií Masarykovy univerzity, 4/2010. S. 85-100. ISSN 1214-813X.

1 Tato stat' vznikla s podporou výzkumného záměru „Reprodukce a integrace společnosti“ (MSM0021622408). Sběr dat zde používaných byl dále finančně podpořen Grantovou agenturou ČR, grant č. 403/08/0999. 
sociologických publikací např́klad srovnání manželství a kohabitací s ohledem na vzdělání, rasu/etnicitu, věk a př́ijem partnerů (např́ílad Kennedy a Bumpass 2008; Kiernan 1996; Manning a Lichter 1999; Nock 1995; Seltzer 2004; Thornton, Axinn a Xie 2007), srovnání úrovně a načasování plodnosti (Rindfuss a VandenHeuvel 1990, Manning 1995), stability (Bumpass a Lu 2000, Kennedy a Bumpass 2008) a kvality vztahu (Brown a Booth 1996), hodnocení spokojenosti se vztahem (Nock 1995), principů soudržnosti (Brines a Joyner 1993), vzorců dělby práce (Gupta 1999), sdílení finančních zdrojů (Heimdal a Houseknecht 2003, Kenney 2004) a podobně.

Mezi prominentní témata těchto srovnání patř́ i srovnání hodnot a postojů lidí žijících v manželstvích a nesezdaných svazcích (srov. Clarkberg, Stolzenberg a Waite 1995). Podle zahraniční literatury jsou lidé žijící v kohabitacích méně často zastánci tradičních rodinných hodnot, mají spíše rovnostářské postoje $\mathrm{k}$ dělbě rolí mezi partnery, častěji přiznávají ženám právo/ambice na seberealizaci mimo domácnost, spíše ospravedlní nevěru nebo rozpad partnerského svazku (srov. Clarkberg, Stolzenberg a Waite 1995; Lye a Waldron 1997; Thornton, Axinn a Xie 2007).

Analýzy hodnotového a postojového profilu lidí v manželstvích a kohabitacích jsou přitom zřejmě populární ze tří odlišných důvodů.

1. Samotný vzestup kohabitací je často vykládán v kontextu teorií o hodnotové změně (např́klad teorie druhé demografické tranzice atp.). Rozšíření kohabitace je vnímáno jako jeden $\mathrm{z}$ indikátorů druhého demografického přechodu (který sám je vysvětlován hodnotovou proměnou v populaci) i jako katalyzátor dalších změn. Proto je důraz na hodnotové (ne) podobnosti pochopitelný a v jistém smyslu nevyhnutelný. Je logické, že se pozornost věnuje zejména hodnotám, které se bezprostředně dotýkají fungování partnerství a domácnosti a plození/rození/výchovy dětí, protože právě měnící se hodnoty v těchto oblastech mohou být příčinou rostoucího výskytu kohabitací.

2. Protože kohabitace jsou místem výchovy dětí, je třeba zmapovat, v jakém hodnotovém prostředí děti vyrůstají, jaké hodnoty si od rodičů osvojují. Více či méně explicitně jsou tato srovnání pokusem nahlédnout budoucnost rodiny, demografického systému a celé společnosti, protože náhrada kohort v populaci je jedním z nejčastěji uvažovaných mechanismů sociální změny (srov. Ryder 1965, Stinchcombe 1968, Spilerman a Gerratana 2009). Budoucí generace budou od současných tím odlišnější, čím odlišnější je hodnotové klima v domácnostech, ve kterých vyrůstají. Jsou-li tyto domácnosti domácnostmi nesezdaných rodičů a jsou-li domácnosti kohabitujících partnerů hodnotově odlišné od domácností manželských, bude odlišnost príštích generací tím větší, čím více dětí se v kohabitacích narodí. Je-li kohabitace katalyzátorem populační změny skrze svou hodnotovou odlišnost, pak se hodnotová srovnání musí zejména soustředit na analýzu hodnot týkajících se rodičovství, partnerství a výchovy.

3. Rozdíly v hodnotovém profilu mezi manželstvím a kohabitací jsou často používány jako explananda všude tam, kde jsou zároveň zjištěny rozdíly v chování. Přesto v takových situacích není hodnotová odlišnost dokládána, ale spíše předpokládána.

Česká sociologie se až do nedávné doby srovnání manželství a kohabitace věnovala jen okrajově, v poslední dekádě ale zájem o tento fenomén rychle narůstal a objevilo se několik srovnávacích studií. Chaloupková (2006) např́ílad doložila, že v letech 1994 až 2002 existovaly mezi manželskými a kohabitujícími páry významné rozdíly v hospodaření s penězi. 
V kohabitacích je sdílení př́ijmu a společné hospodaření méně časté než v manželství. Tyto rozdíly ale zmizí v mnohorozměrných analýzách, jakmile kontrolujeme počet dětí, spokojenost $\mathrm{s}$ rodinným životem, postavení na trhu práce a partnerskou historii (zkušenost s předchozím rozpadlým vztahem). Čeští lidé žijící v manželství a kohabitacích také vykazují odlišnou úroveň životní spokojenosti (Hamplová 2006). Hamplová (2002) dále ukázala, že v kohabitacích častěji než v manželstvích najdeme situace, kdy žena vydělává více než muž. Hamplová (2009) také srovnává vzdělanostní homogamii provdaných a neprovdaných párů v mezinárodním kontextu. Konečně Kreidl a Hrešanová (2007) srovnávají zdraví novorozenců (měřené pomocí porodní hmotnosti) narozených v různých typech rodin a dokládají, že se děti neprovdaných matek rodí s nižší porodní hmotností, a jsou tedy vystaveny větším zdravotním i sociálním rizikům v pozdějším životě. Navzdory těmto informativně bohatým př́íspěvkům však stále nemáme $\mathrm{k}$ dispozici empirické srovnání hodnot a postojů lidí v manželstvích a kohabitacích. Účelem toho textu je tuto mezeru v našem poznání zaplnit.

\section{Výzkumné otázky}

V tomto textu chci s použitím dat z výzkumů European Values Study z let 1991, 1999, 2008 (blíže k tomuto výzkumu viz editoral tohoto čísla) empiricky dokumentovat tři skutečnosti:

1. Zda i v post-socialistické české společnosti existují hodnotové rozdíly mezi lidmi žijícími v manželství a kohabitaci (jak je to typické v jiných moderních demokratických společnostech).

2. Zda jsou tyto rozdíly vysvětlitelné vlivem třetích proměnných, např́íklad odlišnou tendencí mladších a méně vzdělaných lidí preferovat kohabitaci před manželstvím, tj. zda jde o kompoziční efekt, nebo zda zjištěné rozdíly přetrvávají i při statistické kontrole těchto třetích proměnných.

3. Zda jsou tyto rozdíly stabilní $\mathrm{v}$ čase, nebo zda dochází $\mathrm{k}$ hodnotové konvergenci. Ke konvergenci by mohlo docházet např́íklad proto, že je dnes, na rozdíl od dob dřívějších, kohabitace méně sociálně marginálním jevem, a je tedy pravděpodobné, že jedinci, kteří ji volí (a zejména ti, kteří ji volí jako trvalé partnerské uspořádání, tj. ti, kteří v každém průřezovém sociologickém šetření převládají), jsou podobnější zbytku společnosti, než tomu bývalo dříve.

Pro toto srovnání volím - z důvodů vyložených v úvodu - sféru hodnot a postojů, které se vztahují k fungování rodiny, partnerství, plození a výchově dětí. Volba těchto dimenzí jakkoli jsou jejich jednotlivé indikátory voleny do jisté míry arbitrárně, s přihlédnutím k existujícím datům - reflektuje názor, že děti, které vyrůstají v domácnostech nesezdaných rodičů, mohou být ovlivněny odlišným rodinným klimatem a přebírat ne-tradiční hodnoty, postoje a vzorce chování rychlejším tempem než zbytek společnosti. Pokud by tomu tak skutečně bylo, nesezdaná soužití by se stávala katalyzátorem sociální změny. Jejich rozššření by bylo indikátorem probíhajících hodnotových proměn české společnosti, ale zároveň by tyto změny vyvolávalo a podněcovalo. 


\section{Data a proměnné}

V hodnotových a postojových proměnných z výzkumu EVS jsem vybral šest indikátorů, které zachycují různé aspekty hodnotových a postojových rozdílů mezi oběma podobami partnerství. Jde o proměnné měřící 1) souhlas s tvrzením, že dítě potřebuje oba rodiče; 2) otázku, zda respondent schvaluje, když chce žena dítě vychovávat sama bez partnera; 3) otázku měřící souhlas $s$ tvrzením, že předškolní děti trpí bez matky; 4) přesvědčení, že být ženou v domácnosti je stejně smysluplné jako práce za mzdu; 5) přesvědčení, že je ospravedlnitelné mít jako ženatý/vdaná milostný poměr; 6) souhlas s ospravedlnitelností rozvodu. Odpovědi na všech těchto šest otázek byly před dalším zpracováním převedeny do podoby dichotomických proměnných a překódovány tak, aby hodnota 1 vyjadřovala „tradičnějšši“ stanovisko a hodnota 0 stanovisko „méně tradiční“. Otázky měřící souhlas s výrokem typicky nabízely respondentům čtyřbodové škály odpovědí (silně souhlasí, souhlasí, nesouhlasí, silně nesouhlasí), zatímco škály měřící ospravedlnitelnost rozvodu a mimomanželského poměru používaly desetibodovou stupnici, kde póly škály znamenaly, že jde o jednání vždy nebo nikdy ospravedlnitelné. Pro účely dichotomizace byly škály rozděleny přesně v polovině.

Jako klíčovou vysvětlující proměnnou používám indikátor toho, zda respondent žije ve stálém manželském svazku nebo zda kohabituje (respondenty, kteří nežijí v jedné domácnosti s partnerem, do analýzy nezařazuji, a to ani $\mathrm{v}$ úvodních deskriptivních tabulkách). Celkem je v datovém souboru poměr vdaných/ženatých respondentů a respondentů kohabitujících 9:1. Podíl kohabitujících ovšem rostl v čase: v roce 1991 tvořili pouze $5 \%$ ze všech respondentů žjí́cích v partnerských domácnostech, zatímco v roce 1999 jich bylo $12 \%$ a v roce 2008 již více než $15 \%$.

Jako kontrolní proměnné používám pohlaví respondenta (polovina respondentů jsou muži), ${ }^{2}$ věk (rozlišuji tři věkové skupiny: do 30 let, $30-44$ let, 45 a více let), vzdělání (kategorie ZŠ, střední vzdělání bez maturity, střední vzdělání s maturitou, vysokoškolské vzdělání), rok sběru dat (1991, 1999, 2008), počet dětí (kódováno do tř́ kategorií - žádné, jedno, dvě a více) a jejich př́ípadné interakce. ${ }^{3}$

$\mathrm{Z}$ výzkumu EVS používám pouze respondenty, kteří $\mathrm{v}$ roce sběru dat žili $\mathrm{s}$ partnerem v jedné domácnosti a známe jejich pohlaví, věk a vzdělání. Celkem je těchto respondentů 3873. Pro každou z dílčích analýz používám pouze respondenty, kteří uvedli odpověd' na otázku měřící danou závisle proměnnou. Počty platných odpovědí tak $\mathrm{v}$ jednotlivých částech analýzy variují od 3677 po 3819 respondentů (viz tabulku 1).

Pohlaví používám i přesto, že neočekávám, že by vynechání této proměnné mohlo zkreslit odhadnutý vztah mezi typem partnerství a závisle proměnnými, protože pohlaví není korelováno s typem vztahu. Přesto ale může některé čtenáře zajímat efekt pohlaví na partnerské hodnoty a postoje, který je v analýzách zachycen. Asociace každé kontrolní proměnné s klíčovou vysvětlující proměnnou (typem partnerství) je zachycena v př́loze.

3 Vztahy mezi indikátorem typu partnerství a dalšími vysvětlujícími proměnnými v analýze jsou dokumentovány $\mathrm{v}$ príloze. 
Tabulka 1: Souhlas s uvedenými výroky výzkumu EVS v letech 1991, 1999, 2008 podle †ypu partnerství.

\begin{tabular}{|c|c|c|c|}
\hline \multicolumn{4}{|l|}{ Celkem za všechny roky } \\
\hline \multirow{2}{*}{ Výrok } & \multirow{2}{*}{ Souhlas celkem } & \multicolumn{2}{|c|}{ Souhlas podle typu partnerství } \\
\hline & & Manželství & Kohabitace \\
\hline Dítě potřebuje oba rodiče & $\begin{array}{c}91 \% \\
(3802) \\
\end{array}$ & $\begin{array}{c}92 \% \\
(3472) \\
\end{array}$ & $\begin{array}{c}82 \% \\
(375)\end{array}$ \\
\hline $\begin{array}{l}\text { Neschvaluje, když chce žena dítě } \\
\text { vychovávat sama }\end{array}$ & $\begin{array}{c}35 \% \\
(3813) \\
\end{array}$ & $\begin{array}{c}36 \% \\
(3430)\end{array}$ & $\begin{array}{c}26 \% \\
(383)\end{array}$ \\
\hline Předškolní děti trpí bez matky & $\begin{array}{c}55 \% \\
(3784) \\
\end{array}$ & $\begin{array}{c}56 \% \\
(3412) \\
\end{array}$ & $\begin{array}{c}46 \% \\
(372)\end{array}$ \\
\hline $\begin{array}{l}\text { Být v domácnosti je stejně smysluplné jako } \\
\text { placené povolání }\end{array}$ & $\begin{array}{c}75 \% \\
(3677)\end{array}$ & $\begin{array}{c}75 \% \\
(3320)\end{array}$ & $\begin{array}{c}68 \% \\
(357)\end{array}$ \\
\hline $\begin{array}{l}\text { Je neospravedlnitelné mít milostný poměr } \\
\text { jako ženatý/vdaná }\end{array}$ & $\begin{array}{c}89 \% \\
(3819)\end{array}$ & $\begin{array}{c}90 \% \\
(3440)\end{array}$ & $\begin{array}{l}83 \% \\
(379)\end{array}$ \\
\hline Rozvod není ospravedlnitelný & $\begin{array}{c}56 \% \\
(3803)\end{array}$ & $\begin{array}{c}58 \% \\
(3426)\end{array}$ & $\begin{array}{c}44 \% \\
(377)\end{array}$ \\
\hline \multicolumn{4}{|l|}{ Rok 1991} \\
\hline \multirow{2}{*}{ Výrok } & \multirow{2}{*}{ Souhlas celkem } & \multicolumn{2}{|c|}{ Souhlas podle typu partnerství } \\
\hline & & Manželství & Kohabitace \\
\hline Dítě potřebuje oba rodiče & $\begin{array}{c}95 \% \\
(1583)\end{array}$ & $\begin{array}{c}96 \% \\
(1502)\end{array}$ & $\begin{array}{l}85 \% \\
(81)\end{array}$ \\
\hline $\begin{array}{l}\text { Neschvaluje, když chce žena dítě } \\
\text { vychovávat sama }\end{array}$ & $\begin{array}{c}43 \% \\
(1580) \\
\end{array}$ & $\begin{array}{c}44 \% \\
(1499) \\
\end{array}$ & $\begin{array}{l}33 \% \\
(81) \\
\end{array}$ \\
\hline Předškolní děti trpí bez matky & $\begin{array}{c}71 \% \\
(1577) \\
\end{array}$ & $\begin{array}{c}71 \% \\
(1497) \\
\end{array}$ & $\begin{array}{l}68 \% \\
(80) \\
\end{array}$ \\
\hline $\begin{array}{l}\text { Býł v domácnosti je stejně smysluplné jako } \\
\text { placené povolání }\end{array}$ & $\begin{array}{c}84 \% \\
(1545) \\
\end{array}$ & $\begin{array}{c}84 \% \\
(1469) \\
\end{array}$ & $\begin{array}{l}82 \% \\
(76) \\
\end{array}$ \\
\hline $\begin{array}{l}\text { Je neospravedlnitelné mít milostný poměr } \\
\text { jako ženatý/vdaná }\end{array}$ & $\begin{array}{c}90 \% \\
(1595)\end{array}$ & $\begin{array}{c}90 \% \\
(1514)\end{array}$ & $\begin{array}{l}81 \% \\
(81)\end{array}$ \\
\hline Rozvod není ospravedlnitelný & $\begin{array}{c}65 \% \\
(1592) \\
\end{array}$ & $\begin{array}{c}66 \% \\
(1512) \\
\end{array}$ & $\begin{array}{l}53 \% \\
(80) \\
\end{array}$ \\
\hline \multicolumn{4}{|l|}{ Rok 1999} \\
\hline \multirow{2}{*}{ Výrok } & \multirow{2}{*}{ Souhlas celkem } & \multicolumn{2}{|c|}{ Souhlas podle typu partnerství } \\
\hline & & Manželství & Kohabitace \\
\hline Dítě potřebuje oba rodiče & $\begin{array}{c}88 \% \\
(1278)\end{array}$ & $\begin{array}{c}89 \% \\
(1128)\end{array}$ & $\begin{array}{r}85 \% \\
(150)\end{array}$ \\
\hline $\begin{array}{l}\text { Neschvaluje, když chce žena dítě } \\
\text { vychovávat sama }\end{array}$ & $\begin{array}{c}31 \% \\
(1293) \\
\end{array}$ & $\begin{array}{c}32 \% \\
(1136) \\
\end{array}$ & $\begin{array}{c}24 \% \\
(157)\end{array}$ \\
\hline Předškolní děti trpí bez matky & $\begin{array}{c}48 \% \\
(1280) \\
\end{array}$ & $\begin{array}{c}49 \% \\
(1123) \\
\end{array}$ & $\begin{array}{c}41 \% \\
(157)\end{array}$ \\
\hline $\begin{array}{l}\text { Býł v domácnosti je stejně smysluplné jako } \\
\text { placené povolání }\end{array}$ & $\begin{array}{c}78 \% \\
(1256) \\
\end{array}$ & $\begin{array}{c}79 \% \\
(1105) \\
\end{array}$ & $\begin{array}{l}74 \% \\
(151)\end{array}$ \\
\hline $\begin{array}{l}\text { Je neospravedlnitelné mít milostný poměr } \\
\text { jako ženatý/vdaná }\end{array}$ & $\begin{array}{c}90 \% \\
(1290)\end{array}$ & $\begin{array}{c}91 \% \\
(1136)\end{array}$ & $\begin{array}{l}83 \% \\
(154)\end{array}$ \\
\hline Rozvod není ospravedlnitelný & $\begin{array}{c}49 \% \\
(1277) \\
\end{array}$ & $\begin{array}{c}50 \% \\
(1126) \\
\end{array}$ & $\begin{array}{c}41 \% \\
(151)\end{array}$ \\
\hline
\end{tabular}


Tabulka 1 - pokračování

\begin{tabular}{|c|c|c|c|}
\hline \multicolumn{4}{|l|}{ Rok 2008} \\
\hline \multirow{2}{*}{ Výrok } & \multirow{2}{*}{ Souhlas celkem } & \multicolumn{2}{|c|}{ Souhlas podle typu partnerství } \\
\hline & & Manželství & Kohabitace \\
\hline Dítě potřebuje oba rodiče & $\begin{array}{l}87 \% \\
(941)\end{array}$ & $\begin{array}{c}89 \% \\
(797)\end{array}$ & $\begin{array}{c}76 \% \\
(144)\end{array}$ \\
\hline $\begin{array}{l}\text { Neschvaluje, když chce žena dítě } \\
\text { vychovávat sama }\end{array}$ & $\begin{array}{c}28 \% \\
(940)\end{array}$ & $\begin{array}{c}28 \% \\
(795)\end{array}$ & $\begin{array}{c}23 \% \\
(145)\end{array}$ \\
\hline Předškolní děti trpí bez matky & $\begin{array}{l}39 \% \\
(927)\end{array}$ & $\begin{array}{l}39 \% \\
(792)\end{array}$ & $\begin{array}{l}39 \% \\
(135)\end{array}$ \\
\hline $\begin{array}{l}\text { Být v domácnosti je stejně smysluplné jako } \\
\text { placené povolání }\end{array}$ & $\begin{array}{c}52 \% \\
(876) \\
\end{array}$ & $\begin{array}{c}52 \% \\
(746) \\
\end{array}$ & $\begin{array}{c}52 \% \\
(130)\end{array}$ \\
\hline $\begin{array}{l}\text { Je neospravedlnitelné mít milostný poměr } \\
\text { jako ženatý/vdaná }\end{array}$ & $\begin{array}{c}87 \% \\
(934)\end{array}$ & $\begin{array}{c}87 \% \\
(790)\end{array}$ & $\begin{array}{c}83 \% \\
(144)\end{array}$ \\
\hline Rozvod není ospravedlnitelný & $\begin{array}{c}51 \% \\
(934)\end{array}$ & $\begin{array}{l}53 \% \\
(788)\end{array}$ & $\begin{array}{c}43 \% \\
(146)\end{array}$ \\
\hline
\end{tabular}

Poznámka: V závorce jsou uvedeny procentní základy. Tabulka zachycuje pouze respondenty, kteři v době dotazování žili v jedné domácnosti s partnerem.

Tabulka 1 zachycuje celkovou míru souhlasu s jednotlivými výroky (závisle proměnnými). Vidíme, že celkem $91 \%$ respondentů souhlasí s tím, že dítě potřebuje oba rodiče, $35 \%$ respondentů neschvaluje, když chce žena vychovávat dítě sama bez partnera, a 55\% dotázaných si myslí, že předškolní děti bez matky trpí. Celkem tři čtvrtiny respondentů souhlasí s tím, že být v domácnosti je stejně smysluplné jako placené povolání, $89 \%$ dotázaných se kloní k názoru, že milostný poměr mimo manželství není ospravedlnitelný, a konečně $56 \%$ se domnívá, že rozvod není ospravedlnitelný (viz tabulku 1). Tabulka 1 mimo celkových procentních distribucí závisle proměnných zahrnuje údaje o distribucích závisle proměnných i v každém roce zvlášt'.

\section{Existují rozdíly podle typu partnerství?}

U všech otázek existuje rozdílná míra souhlasu v závislosti na současné podobě partnerství, přičemž platí, že lidé žijící v manželství se kloní ke konzervativnější odpovědi (jedinou výjimkou z tohoto pravidla jsou odpovědi na otázky, zda předškolní dítě trpí bez matky a zda je placené povolání stejně smysluplné jako být ženou v domácnosti, u kterých v roce 2008 nezjistíme žádný rozdíl podle typu partnerství).

Zatímco $92 \%$ lidí žijících v manželství souhlasí s tím, že dítě potřebuje oba rodiče, v kohabitacích žijící jedinci souhlasí jen v $82 \%$ př́padů. Podobně se liší odpovědi u výroku, že není ospravedlnitelné, aby žena chtěla vychovávat dítě sama bez partnera (souhlasí 36\% lidí v manželství a $26 \%$ v kohabitacích), a u výroku, že předškolní děti trpí bez matky (56\% u ženatých/vdaných vs. $46 \%$ u kohabitujících). Dále $75 \%$ vdaných/ženatých souhlasí s tím, že být doma je stejně smysluplné jako placené povolání, zatímco u kohabitujících je míra souhlasu jen 68 \%. Milostný poměr mimo manželství není ospravedlnitelný pro $90 \%$ lidí, kteří žijí v manželství, zatímco pouze 83 \% kohabitujících tuto situaci odsuzuje. Konečně rozvod 
je neospravedlnitelný pro $58 \%$ lidí v manželství a pro $44 \%$ kohabitantů (viz Tabulku 1, která rovněž umožňuje srovnání rozdílů podle typu partnerství v každém roce zvlášt').

U všech závisle proměnných pozorujeme podobný vývoj odpovědí v čase (viz tabulku 1). Respondenti, jejichž odpovědi využívám $\mathrm{v}$ této analýze, se stále více kloní $\mathrm{k}$ méně tradičním odpovědím. Napríklad souhlas s tvrzením, že dítě potřebuje oba rodiče, klesl mezi lety 1991 a 2008 z původních $95 \%$ na $87 \%$ a u tvrzení, že předškolní dítě trpí bez matky, ze $71 \%$ na $39 \%$. Procento lidí, kteří neschvalují, když chce žena vychovávat dítě sama bez partnera, pokleslo za stejné období ze $43 \%$ na $28 \%$. Zatímco v roce 1991 si $84 \%$ respondentů myslelo, že být v domácnosti je stejně smysluplné jako pracovat za mzdu, v roce 2008 souhlasilo s tímto výrokem jen $52 \%$ lidí, kteří žijí v jedné domácnosti s partnerem. Podobně narostla ospravedlnitelnost rozvodu. Pouze u ospravedlnitelnosti mimomanželských milostných vztahů nepozorujeme mezi lety 1991 a 2008 žádný zřetelný trend.

\section{Jsou existující rozdíly vysvětlitelné kompozičním efekłem?}

Zjištěné rozdíly mezi manželstvím a kohabitací mohou být důsledkem toho, že odlišní lidé mohou preferovat odlišné partnerské uspořádání. Například lidé mladší a méně vzdělaní mohou častěji volit kohabitaci (at' už jako dočasné nebo trvalé partnerské uspořádání). Věk a vzdělání ale zároveň stratifikují hodnoty a postoje. Podobně platí, že ve sledovaném období docházelo obecně k oslabování tradičních hodnot a postojů (a zároveň k rozšsiření kohabitací). Proto je obtížné připsat výše zjištěné rozdíly v hodnotách a postojích mezi manželstvím a kohabitací čistě kauzálnímu efektu formy partnerství. Může jít o nepravý efekt způsobený vlivem třetích proměnných, které jsou jak ve vztahu k partnerskému uspořádání, tak ve vztahu k měřeným závisle proměnným v pozici společné prríčiny.

Abychom mohli vyloučit tuto možnost, musíme použít vícerozměrný statistický model, kterým bude možné třetí proměnné kontrolovat. Protože jsem v předchozí analýze používal všechny závisle proměnné $\mathrm{v}$ dichotomizované podobě, je vhodným nástrojem mnohorozměrné statistiky model logistické regrese. Analýza u každé závisle proměnné postupuje ve dvou krocích. V prvním kroku odhadnu základní model, v němž je typ partnerského svazku jediným prediktorem, a ve druhém kroku přidám do modelu všechny kontrolní proměnné.

Tento druhý, rozšiřrený model má tedy u každé závisle proměnné tuto podobu:

$$
\begin{aligned}
& \ln \left(\frac{P_{T} \mid X}{P_{N} \mid X}\right)=a+\sum_{i=1}^{2} b_{i} * \operatorname{rok}_{i}+c * \text { kohabitace }+d * m u \check{z}+\sum_{i=1}^{3} e_{i} * \text { vzdělání }+ \\
& \sum_{i=1}^{2} f_{1} * v e ̌ k+\sum_{i=1}^{2} g_{1} * d e ̌ t i
\end{aligned}
$$

V modelu je $P_{T}$ pravděpodobnost, že respondent na danou otázku odpoví v souladu s tradičními představami o partnerství a rodině, a $P_{N}$ je pravděpodobnost odpovědi „ne-tradiční“. Platí, že $P_{T}+P_{N}=1$. Rok (sběru dat), kohabitace, muž, vzdělání, věk a děti jsou jednotlivé vysvětlující proměnné popsané výše; nominální i ordinální vysvětlující proměnné byly pro potřeby této analýzy dichotomizovány do podoby binárních kontrastů. Koeficienty $b_{i}, c, d, e_{i}$, $f_{i}, g_{i}$ jsou potom jejich odhadnuté efekty a konečně $a$ je konstanta, která vyjadřuje z modelu 
odhadnutou hodnotu levé strany rovnice, pokud jsou všechny další členy na pravé straně rovnice rovny nule.

Srovnáním modelů ověřujeme, zda (prrípadně do jaké míry) po přidání kontrol oslabí původní celkový efekt typu partnerského svazku. Tato srovnání jsou prezentována $\mathrm{v}$ tabulce 2. Základní modely pouze potvrzují to, co již jsme viděli v dvourozměrných tabulkách: lidé v manželství jsou ve svých hodnotách a postojích „,tradičnější““ než kohabitující a tento efekt je u všech závisle proměnných statisticky významný na hladině 0,005 . Vidíme dále, že u všech šesti závisle proměnných po přidání kontrol (věk, pohlaví, vzdělání, rok sběru dat, počet dětí) původní efekt typu partnerství významně oslabí. V jednom případě (,„předškolní dítě trpí bez matky“) efekt zcela vymizí. V jednom případě (,být ženou v domácnosti je stejně smysluplné jako práce za mzdu“) efekt poklesne o devět desetin a je statisticky nevýznamný. U ostatních závisle proměnných efekt oslabí o jednu polovinu až jednu třetinu, ale zůstává i nadále statisticky významný přinejmenším na hladině 0,1 .

Tabulka 2: Odhadnuté efekty typu partnerství (kohabitace vs. manželství) na přirozený logaritmus šance, že respondent bude souhlasit s uvedenými výroky, z různých modelů binární logistické regrese.

\begin{tabular}{|l|c|c|c|}
\hline & Bez kontrol (1) & $\begin{array}{c}\text { Při kontrole roku, počtu dětí, pohlaví, } \\
\text { vzdělání a věku (2) }\end{array}$ & Poměr 2/1 \\
\hline Oba rodiče & $-0,912^{* * *}$ & $-0,426^{* * *}$ & 0,47 \\
\hline Pouze matka & $-0,499^{* * *}$ & $-0,250^{*}$ & 0,51 \\
\hline Dítě trpí & $-0,426^{* * *}$ & 0,013 & 0,03 \\
\hline Být ženou v domácnosti & $-0,371^{* * *}$ & $-0,041$ & 0,11 \\
\hline Milostný poměr & $-0,628^{* * *}$ & $-0,429^{* *}$ & 0,68 \\
\hline Rozvod & $-0,536^{* * *}$ & $-0,330^{* *}$ & 0,62 \\
\hline
\end{tabular}

Poznámka: Závisle proměnné jsou vždy kódovány tak, že „,tradičnější" odpověd' je 1; záporný efekt tedy znamená, že kohabitující jedinci jsou méně „ tradiční".

Tabulka zachycuje pouze respondenty, kteři v době dotazování žili v jedné domácnosti s partnerem.

*** - Statisticky významné na hladině 0,005. ** - Statisticky významné na hladině 0,05. * - Statisticky významné na hladině 0,1 .

Odhadnuté parametry rozšířených modelů prezentované v tabulce 3 si zaslouží krátký komentár. Vidíme, že odpovědi respondentů se od začátku devadesátých let minulého století posouvají u všech závisle proměnných směrem k méně tradičním odpovědím. Muži obvykle dávají tradičnější odpovědi než ženy a respondenti s nižším vzděláním jsou ve svých hodnotách a postojích tradičnější než respondenti s vyšším vzděláním. Příklon k tradičním hodnotám a postojům také roste $\mathrm{s}$ věkem $\mathrm{a}-\mathrm{v}$ prrípadě otázky, zda dítě potřebuje oba rodiče - také s počtem dětí.

Ve většině případů není pozorovaný efekt typu partnerství na hodnoty a postoje vysvětlitelný pouhým odlišným složením manželství a kohabitací s ohledem na rok výzkumu, věk respondenta, počet dětí a vzdělání. Existují nicméně další proměnné, které mohou zároveň ovlivňovat volbu partnerského uspořádání i hodnoty. Proto tato analýza není definitivním závěrem ohledně kauzálního efektu kohabitace na hodnoty a postoje, ale pouze naznačením této možnosti. K definitivnímu postulování prríčinného efektu by zřejmě bylo třeba mít 
$\mathrm{k}$ dispozici data $\mathrm{z}$ longitudinální panelové studie, $\mathrm{v}$ níž by hodnoty a postoje (stejně jako partnerská situace) byly měřeny u stejných respondentů opakovaně, a bylo by tedy možné doložit efekt partnerského uspořádání na změnu $\mathrm{v}$ deklarovaných hodnotách a postojích. Panelová data tohoto druhu však v ČR zatím nemáme $\mathrm{k}$ dispozici.

Tabulka 3: Odhadnuté efekty modelů binární logistické regrese predikující souhlas s různými výroky ve výzkumu EVS v letech 1991, 1999, 2008.

\begin{tabular}{|c|c|c|c|c|c|c|}
\hline & $\begin{array}{l}\text { Oba } \\
\text { rodiče }\end{array}$ & $\begin{array}{l}\text { Pouze } \\
\text { matka }\end{array}$ & Dítě trpí & $\begin{array}{c}\text { Být ženou } \\
\text { v domácnosti }\end{array}$ & $\begin{array}{l}\text { Milostný } \\
\text { poměr }\end{array}$ & Rozvod \\
\hline \multicolumn{7}{|l|}{ Rok (1991 je ref. kategorie) } \\
\hline 1999 & $\begin{array}{l}-0,946 \\
(0,150)\end{array}$ & $\begin{array}{l}-0,568 \\
(0,082)\end{array}$ & $\begin{array}{l}-1,022 \\
(0,082)\end{array}$ & $\begin{array}{l}-0,395 \\
(0,100)\end{array}$ & $\begin{array}{c}0,108 \\
(0,128)\end{array}$ & $\begin{array}{l}-0,661 \\
(0,079)\end{array}$ \\
\hline 2008 & $\begin{array}{l}-1,025 \\
(0,158)\end{array}$ & $\begin{array}{l}-0,711 \\
(0,093)\end{array}$ & $\begin{array}{l}-1,385 \\
(0,092)\end{array}$ & $\begin{array}{l}-1,555 \\
(0,101)\end{array}$ & $\begin{array}{l}-0,302 \\
(0,132)\end{array}$ & $\begin{array}{l}-0,541 \\
(0,087)\end{array}$ \\
\hline Kohabitace (vs. manželství) & $\begin{array}{l}-0,426 \\
(0,175)\end{array}$ & $\begin{array}{l}-0,250 \\
(0,134)\end{array}$ & $\begin{array}{c}0,013 \\
(0,127)\end{array}$ & $\begin{array}{l}-0,041 \\
(0,142)\end{array}$ & $\begin{array}{l}-0,429 \\
(0,168)\end{array}$ & $\begin{array}{l}-0,330 \\
(0,122)\end{array}$ \\
\hline Muž & $\begin{array}{c}0,626 \\
(0,120)\end{array}$ & $\begin{array}{c}0,309 \\
(0,071)\end{array}$ & $\begin{array}{c}0,435 \\
(0,071)\end{array}$ & $\begin{array}{c}0,501 \\
(0,082)\end{array}$ & $\begin{array}{l}-0,433 \\
(0,108)\end{array}$ & $\begin{array}{c}0,005 \\
(0,068)\end{array}$ \\
\hline \multicolumn{7}{|c|}{ Vzdělání (ZŠ nebo nižší je ref. kategorie) } \\
\hline Vyučení & $\begin{array}{l}-0,292 \\
(0,198)\end{array}$ & $\begin{array}{l}-0,168 \\
(0,108)\end{array}$ & $\begin{array}{l}-0,242 \\
(0,113)\end{array}$ & $\begin{array}{l}-0,438 \\
(0,139)\end{array}$ & $\begin{array}{c}0,096 \\
(0,171)\end{array}$ & $\begin{array}{l}-0,157 \\
(0,109)\end{array}$ \\
\hline SŠ s maturitou & $\begin{array}{l}-0,105 \\
(0,202) \\
\end{array}$ & $\begin{array}{l}-0,250 \\
(0,111) \\
\end{array}$ & $\begin{array}{l}-0,419 \\
(0,115) \\
\end{array}$ & $\begin{array}{l}-0,416 \\
(0,140) \\
\end{array}$ & $\begin{array}{c}0,046 \\
(0,174) \\
\end{array}$ & $\begin{array}{l}-0,353 \\
(0,111) \\
\end{array}$ \\
\hline VŠ & $\begin{array}{l}-0,245 \\
(0,236)\end{array}$ & $\begin{array}{l}-0,418 \\
(0,139)\end{array}$ & $\begin{array}{l}-0,499 \\
(0,139)\end{array}$ & $\begin{array}{l}-0,373 \\
(0,168)\end{array}$ & $\begin{array}{c}0,107 \\
(0,212)\end{array}$ & $\begin{array}{l}-0,549 \\
(0,133)\end{array}$ \\
\hline \multicolumn{7}{|l|}{ Věk (do 30 let je ref. Kategorie) } \\
\hline 30-44 let & $\begin{array}{l}-0,065 \\
(0,175)\end{array}$ & $\begin{array}{c}0,135 \\
(0,118) \\
\end{array}$ & $\begin{array}{c}0,420 \\
(0,113)\end{array}$ & $\begin{array}{c}0,005 \\
(0,130) \\
\end{array}$ & $\begin{array}{c}0,347 \\
(0,158)\end{array}$ & $\begin{array}{l}-0,108 \\
(0,110)\end{array}$ \\
\hline 45 a více let & $\begin{array}{c}0,374 \\
(0,174)\end{array}$ & $\begin{array}{c}0,630 \\
(0,112)\end{array}$ & $\begin{array}{c}0,792 \\
(0,109)\end{array}$ & $\begin{array}{c}0,113 \\
(0,125)\end{array}$ & $\begin{array}{c}0,628 \\
(0,154)\end{array}$ & $\begin{array}{c}0,261 \\
(0,105)\end{array}$ \\
\hline \multicolumn{7}{|c|}{ Počet dětí (žádné je ref. kategorie) } \\
\hline Jedno & $\begin{array}{c}0,481 \\
(0,214)\end{array}$ & $\begin{array}{c}0,046 \\
(0,154)\end{array}$ & $\begin{array}{c}0,010 \\
(0,151)\end{array}$ & $\begin{array}{c}0,084 \\
(0,168)\end{array}$ & $\begin{array}{c}0,098 \\
(0,207)\end{array}$ & $\begin{array}{c}0,138 \\
(0,144)\end{array}$ \\
\hline Dvě a více & $\begin{array}{c}0,569 \\
(0,203)\end{array}$ & $\begin{array}{l}-0,048 \\
(0,145)\end{array}$ & $\begin{array}{c}0,040 \\
(0,143)\end{array}$ & $\begin{array}{c}0,190 \\
(0,160)\end{array}$ & $\begin{array}{c}0,022 \\
(0,197)\end{array}$ & $\begin{array}{c}0,143 \\
(0,136)\end{array}$ \\
\hline Konstanta & $\begin{array}{c}2,287 \\
(0,274)\end{array}$ & $\begin{array}{l}-0,548 \\
(0,175)\end{array}$ & $\begin{array}{c}0,432 \\
(0,174)\end{array}$ & $\begin{array}{c}1,597 \\
(0,204)\end{array}$ & $\begin{array}{c}1,922 \\
(0,246)\end{array}$ & $\begin{array}{c}0,669 \\
(0,167)\end{array}$ \\
\hline LL & $-1092,36$ & $-2379,10$ & $-2386,67$ & $-1909,21$ & $-1282,56$ & $-2524,10$ \\
\hline
\end{tabular}

Poznámka: Tabulka zachycuje pouze respondenty, kłeři v době dotazování žli v jedné domácnosti s partnerem.

\section{Jak významné jsou hodnotové rozdíly mezi manželstvím a kohabitací?}

Viděli jsme, že hodnotové rozdíly mezi manželstvím a kohabitací existují a nejsou zcela vysvětlitelné odlišným složením manželství a kohabitací s ohledem na věk, vzdělání a počet dětí. Pozorovali jsme dále, že se tyto rozdíly př́liš nemění $\mathrm{v}$ čase. Jak významné však tyto přetrvávající rozdíly jsou? Jde o efekty věcně významné? V této sekci textu se - mimo jiné 
srovnáním s efekty jiných statusových proměnných - pokusím ukázat, že zjištěné rozdíly mezi manželstvím a kohabitací jsou netriviální, věcně zajímavé a neopominutelné.

S použitím binární logistické regrese (viz tabulku 3) jsme zjistili, že u čtyř závisle proměnných (otázky, zda dítě potřebuje oba rodiče; zda dítě může vychovávat sama matka; zda je ospravedlnitelný rozvod a mimomanželský poměr) existuje statisticky významný čistý efekt typu partnerství. Síla těchto efektů se pohybuje (po zaokrouhlení) od -0,25 do -0,43. Tento efekt vyjadřuje očekávanou změnu přirozeného logaritmu šance, že respondent bude souhlasit s daným výrokem. Tento efekt můžeme pro lepší ilustraci vyjádřit i v termínech změn v pravděpodobnosti souhlasu. Protože je však průběh logistické funkce nelineární, musíme takovou evaluaci provést pro konkrétní hodnoty všech dalších vysvětlujících proměnných. Jako ilustraci volím dva „profily“, u nichž ukazuji čistý efekt kohabitace (ve srovnání s manželstvím) na pravděpodobnost souhlasu s daným výrokem.

1. Vyučený muž ve věku 30-44 let se dvěma dětmi v roce 1999.

2. Bezdětná vysokoškolačka ve věku 18-29 let v roce 2008.

Výsledky evaluace logitových modelů jsou prezentovány v tabulce 4 . V textu príitom komentuji pouze modely, u nichž jsme zjistili statisticky významný čistý efekt typu partnerství na závisle proměnnou. Jde tedy o modely predikující souhlas s výrokem, že dítě potřebuje oba rodiče, vyjádření nesouhlasu s představou, že by žena chtěla vychovávat dítě sama bez partnera, a názor, že rozvod a mimomanželský milostný poměr nejsou ospravedlnitelné.

Tabulka 4: Odhadnutý efekt kohabitace (ve srovnání s manželstvím) na pravděpodobnost souhlasu s danými výroky výzkumu EVS v letech 1991, 1999, 2008 pro vybrané profily respondentů.

\begin{tabular}{|l|c|c|}
\hline Závisle proměnná & $\begin{array}{c}\text { Profil 1: Vyučený muž ve věku 30-44 } \\
\text { let se dvěma dětmi v roce 1999 }\end{array}$ & $\begin{array}{c}\text { Profil 2: Bezdětná vysokoškolačka } \\
\text { ve věku 18-29 let v roce 2008. }\end{array}$ \\
\hline Oba rodiče & $-4,6 \%$ & $-9,0 \%$ \\
\hline Pouze matka & $-4,9 \%$ & $-3,1 \%$ \\
\hline Dítě trpí & $+0,3 \%$ & $+0,2 \%$ \\
\hline Být ženou v domácnosti & $-0,6 \%$ & $-1,0 \%$ \\
\hline Milostný poměr & $-5,1 \%$ & $-6,4 \%$ \\
\hline Rozvod & $-8,1 \%$ & $-7,5 \%$ \\
\hline
\end{tabular}

Pozn.: Odhady jsou založené na modelech z tabulky 3.

U prvního výroku (dítě potřebuje oba rodiče) je čistý efekt kohabitace $-4,6 \%$ (první profil), respektive $-9,0 \%$ (druhý profil). U druhého výroku (respondent neschvaluje, když chce žena vychovávat dítě sama) jde o $-4,9 \%$, respektive $-3,1 \%$, u páté závisle proměnné (respondent se domnívá, že mimomanželský milostný poměr není ospravedlnitelný) je efekt $-5,1 \%$, respektive $-6,4 \%$. Konečně u ospravedlnitelnosti rozvodu je efekt u prvního profilu $-8,1 \%$ a u profilu druhého $-7,5 \%$. Zdá se tedy, že jde o efekty sice mírné, přesto však neopominutelné.

Druhou relevantní dimenzí je srovnání s efekty jiných statusových proměnných v modelu. Viděli jsme, že efekt kohabitace dosahuje při kontrole dalších proměnných hodnoty mezi -0,25 a -0,43 (komentuji pouze statisticky významné efekty). Pro srovnání, ve stejných modelech je efekt pohlaví od $+0,63$ do -0, 43 a efekt vysokoškolského vzdělání 
(kontrast VŠ vs. ZŠ) variuje mezi -0,42 a 0,11. Efekt věku (nejvyšší vs. nejnižší kategorie) se pohybuje od 0,63 do 0,26 a efekt počtu dětí (dvě a více vs. žádné) pak leží v intervalu od $-0,05$ do 0,57 . Jde tedy o efekty rrádově stejně silné, jako je efekt kohabitace. Proto hodnotím čistý efekt kohabitace jako věcně významný.

\section{Dochází ke konvergenci hodnot mezi manželstvím a kohabitací?}

Poslední část analýzy se věnuje možné konvergenci hodnotového profilu lidí žijících v manželstvích a nesezdaných soužití. Tato hypotéza vychází z předpokladu, že pokud se nějaký sociální fenomén proměňuje a stává se masivnější záležitostí, procesy samo-výběru se budou oslabovat. Nové vzorce chování bývají zpočátku zpravidla výsadou vybraných sociálních skupin a teprve postupně se šírí i do dalších segmentů společnosti. Tím může docházet $\mathrm{k}$ tomu, že se rozdíly mezi oběma formami partnerství budou snižovat.

Hypotézu o konvergenci ověruji pomocí výše použitých modelů logistické regrese. Mezi prediktory $\mathrm{v}$ těchto modelech přidávám dodatečný interakční člen - interakci mezi rokem a typem partnerství. Model i s interakcemi pak lze formálně vyjádřit takto:

$$
\begin{aligned}
& \ln \left(\frac{P_{T} \mid X}{P_{N} \mid X}\right)=a+\sum_{i=1}^{2} b_{i} * \text { rok }_{i}+c * \text { kohabitace }+d * m u \check{z}+\sum_{i=1}^{3} e_{i} * \text { vzdèlání } \\
& \sum_{i=1}^{2} f_{1} * v e ̌ k+\sum_{i=1}^{2} g_{1} * d e ̌ t i+\sum_{i=1}^{2} h_{1} * \text { rok } * \text { kohabitace }
\end{aligned}
$$

V modelu 2 potom testujeme statistickou významnost sady koeficientů $h_{i}$, kterou lze zhodnotit např́klad pomocí testu poměrem maxim věrohodnostních funkcí u modelu 1 a modelu 2, př́ípadně pomocí Waldova testu aplikovaného na model 2. Oba testy jsou v principu asymptoticky shodné, přesto se $\mathrm{v}$ analytické praxi někdy vyskytnou situace, že každý test vede k odlišnému výsledku. Statistici obvykle preferují věrohodnostní test (srov. Freese a Long 2006), v tabulce 5 však uvádím výsledky testování pomocí obou testových alternativ.

Tabulka 5: Výsledky testu statistické významnosti interakce mezi rokem a formou partnerství podle použité vysvětlované proměnné. Modely binární logistické regrese.

\begin{tabular}{|l|c|c|c|c|}
\hline & \multicolumn{2}{|c|}{$\begin{array}{c}\text { Test poměrem maxim } \\
\text { věrohodnostních funkcí }\end{array}$} & X2 & p-hodnota \\
\hline Závisle proměnná & L2 & p-hodnota & 8,57 & 0,014 \\
\hline Oba rodiče & 8,20 & 0,017 & 0,84 & 0,656 \\
\hline Pouze matka & 0,85 & 0,655 & 2,94 & 0,230 \\
\hline Dítě trpí & 2,91 & 0,234 & 1,74 & 0,418 \\
\hline Být ženou v domácnosti & 1,73 & 0,421 & 2,16 & 0,339 \\
\hline Milostný poměr & 2,18 & 0,336 & 1,38 & 0,502 \\
\hline Rozvod & 1,37 & 0,503 & \\
\hline
\end{tabular}

Poznámka: Interakce je dodávána do modelu se všemi kontrolními proměnnými (viz třetí sloupec v tabulce 2 nebo modely $v$ tabulce 3). Protože forma partnerství má dvě kategorie a rok sběru dat tři kategorie, použitý chí-kvadrát test má vždy dva stupně volnosti.

Testy přesvědčivě a konzistentně ukazují, že u pěti závisle proměnných můžeme hypotézu o konvergenci bez obav zamítnout. U těchto proměnných tedy zůstává neměnný rozdíl 
v odpovědích mezi jedinci žijícími v manželství a kohabitaci. Pouze u šesté závisle proměnné (odpověd' na otázku, zda dítě potřebuje oba rodiče) je zřejmé, že se rozdíl v odpovědích mění v čase (test statistické významnosti interakce mezi rokem a typem partnerství je významný na hladině 0,05 jak u věrohodnostního, tak u Waldova testu).

Tabulka 6: Odhadnuté efekty a směrodatné chyby modelu binární logistické regrese, kde závisle proměnnou je souhlas s výrokem, že dítě potřebuje oba rodiče.

\begin{tabular}{|c|c|c|}
\hline Rok (1991 je ref. kategorie) & $B$ & S.E.(b) \\
\hline 1999 & $-1,102$ & 0,161 \\
\hline 2008 & $-1,087$ & 0,174 \\
\hline Kohabitace (vs. manželství) & $-1,211$ & 0,344 \\
\hline Muž & 0,626 & 0,120 \\
\hline \multicolumn{3}{|c|}{ Vzdělání (ZŠ nebo nižší je ref. kategorie) } \\
\hline Vyučení & $-0,273$ & 0,198 \\
\hline SŠ s maturitou & $-0,107$ & 0,202 \\
\hline VŠ & $-0,247$ & 0,236 \\
\hline \multicolumn{3}{|l|}{ Věk (do 30 let je ref. kategorie) } \\
\hline 30-44 let & $-0,046$ & 0,176 \\
\hline 45 a více let & 0,391 & 0,175 \\
\hline \multicolumn{3}{|c|}{ Počet dětí (žádné je ref. kategorie) } \\
\hline Jedno & 0,528 & 0,214 \\
\hline Dvě a více & 0,617 & 0,203 \\
\hline \multicolumn{3}{|l|}{ Interakce: Rok*kohabitace } \\
\hline 1999*kohabitace & 1,252 & 0,431 \\
\hline 2008*kohabitace & 0,710 & 0,418 \\
\hline Konstanta & 1,252 & 0,431 \\
\hline $\mathrm{LL}$ & \multicolumn{2}{|c|}{$-1088,26$} \\
\hline
\end{tabular}

Pozn.: Závisle proměnná je kódována takto: 1- souhlasí, že dítě potřebuje oba rodiče; 0 -nesouhlasí, že dítě potřebuje oba rodiče.

Tabulka zachycuje pouze respondenty, kteří v době dotazování žli v jedné domácnosti s partnerem.

Povahu této interakce odhalují odhadnuté efekty prezentované v tabulce 6 . V ní vidíme, že efekt kohabitace byl v roce 1991 velmi silný $(-1,211)$, ale v následujících letech tento efekt oslabuje (v roce 1999 činí efekt typu partnerství $+0,041=-1,211+1,252$, v roce 2008 pak $-0,501=-1,211+0,710$, viz tabulku 6). Pouze u této proměnné se tedy efekt typu partnerství změnil; a změnil se očekávaným způsobem - oslabil až k nule. Máme tedy jen dílčí a omezenou evidenci o tom, že k hodnotové konvergenci mezi manželstvím a kohabitací skutečně dochází.

\section{Závěrečná diskuse}

Tento text si kladl tři dílčí cíle: 1) odhalit a kvantifikovat rozdíly v hodnotách a postojích lidí žijících v manželstvích a neformálních svazcích (kohabitacích); 2) zjistit, zda tyto rozdíly přetrvávají i při kontrole dalších proměnných (věk, vzdělání, počet dětí, rok sběru dat); 3) ověřit, zda v hodnotovém profilu obou typů partnerství dochází ke konvergenci. 
Pomocí popisných i mnohorozměrných statistik aplikovaných na česká data z výzkumů EVS jsem ukázal, že rozdíly mezi manželstvím a kohabitací existují, jsou netriviální a přetrvávají i při statistické kontrole odlišného složení obou typů partnerství s ohledem na věk, vzdělání, počet dětí a rok šetření. Viděli jsme dále, že rozdíly v hodnotovém profilu lidí v manželstvích a nesezdaných soužitích jsou v čase stabilní; našli jsme jen velmi omezený doklad dílčí hodnotové konvergence obou typů partnerství.

Závěr mnohorozměrné analýzy je, že pozorované rozdíly v hodnotách a postojích nejsou způsobeny pouze odlišnou tendencí lidí s určitými charakteristikami preferovat manželství před kohabitací (i když tato tendence dílčím způsobem hodnotové rozdíly spolu-utváří). I při statistické kontrole počtu dětí, vzdělání, roku a věku stále zbývá řada rozdílů v hodnotovém profilu manželství i kohabitací. Je lákavé tyto rozdíly interpretovat jako kauzální efekt typu partnerství na hodnoty a postoje.

Na základě těchto výsledků bychom mohli spekulovat o tom, že odlišný způsob fungování kohabitací (například odlišné vzorce dělby práce, trávení času, interakce se širší rodinou a podobně) může být příčinou proměny hodnot a postojů. Takový závěr je však předčasný, protože jsme pro analýzu měli $\mathrm{k}$ dispozici pouze prưrezová data a byli jsme schopni statisticky kontrolovat pouze malou část proměnných, které mohou ovlivňovat jak stávající hodnoty a postoje respondenti̊, tak jejich partnerské chování. Jde zejména o minulé hodnoty, postoje a chování, které přirozeně mají vliv na hodnoty a postoje současné a mohou také hrát svou roli při rozhodování, zda vstoupit do manželství nebo preferovat neformální svazek.

Rozlišit přesně a s definitivní platností směr a rozsah vzájemného kauzálního působení hodnot a partnerského uspořádání je s existujícími daty nemožné, a proto připomínám deskriptivní význam prezentovaných rozdílů. Konstatovat přesvědčivěji kauzální efekty typu partnerství na hodnoty by bylo možné pouze s daty z panelového šetření, v němž by jak hodnoty a postoje, tak i partnerský status byly zjištovány opakovaně u týchž respondentů. Tak bychom mohli modelovat např́klad vliv současného typu partnerství a na změnu hodnot od posledního rozhovoru, nebo vliv typu partnerství na současné hodnoty při statistické kontrole hodnot z posledního rozhovoru (statisticky jde o ekvivalentní postupy). Data podobného charakteru zatím česká sociologie nemá $\mathrm{k}$ dispozici, a proto tyto zásadní otázky ohledně vlivu hodnot na partnerství a vlivu partnerství na hodnoty nemůžeme zcela uspokojivě zodpovědět.

Proto tento text pouze naznačil, že typ partnerství hodnoty může ovlivňovat, může na ně mít dodatečný efekt, který jde nad rámec bezpochyby existujícího samo-výběru (srov. Thornton, Axinn a Hill 1992). Kohabitace jsou přirozeně preferovaným typem partnerského uspořádání pro lidi liberální, rovnostářské, pro lidi, kteří se odklánějí od tradičních představ o dělbě partnerských rolí. Mimo to ale může, bez ohledu na vstupní hodnotový profil partnerů, kohabitace fungovat jako katalyzátor změny: lidé žijící v kohabitacích se v důsledku kohabitace stávají liberálnějšími, rovnostářštějšími a méně tradičními (srov. Axinn a Thornton 1993; Thornton, Axinn a Hill 1992; viz také Seltzer 2004; Smock 2000; Thornton, Axinn a Xie 2007). Potom by ale také platilo, že čím více lidí bude v kohabitacích žít a čím více lidí bude v neformálních svazcích plodit, rodit a vychovávat děti, tím rychlejší bude hodnotová proměna současné české společnosti. K robustnějšímu potvrzení tohoto, zatím jen předběžného závěru, ale musíme počkat na nová, longitudinální panelová data. 


\section{Příloha: Procentní distribuce typu partnerství v kategoriích} kontrolních proměnných $\mathrm{v}$ analýze.

\begin{tabular}{|c|c|}
\hline Kontrolní proměnná & \% kohabitujících \\
\hline \multicolumn{2}{|l|}{ Rok } \\
\hline 1991 & $\begin{array}{c}5 \% \\
(1601)\end{array}$ \\
\hline 1999 & $\begin{array}{c}12 \% \\
(1305)\end{array}$ \\
\hline 2008 & $\begin{array}{c}15 \% \\
(967)\end{array}$ \\
\hline \multicolumn{2}{|l|}{ Pohlaví } \\
\hline Muž & $\begin{array}{c}10 \% \\
(1935)\end{array}$ \\
\hline Žena & $\begin{array}{c}10 \% \\
(1938)\end{array}$ \\
\hline \multicolumn{2}{|l|}{ Vzdělání } \\
\hline ZŠ nebo nižší & $\begin{array}{c}12 \% \\
(528)\end{array}$ \\
\hline Vyučení & $\begin{array}{c}9 \% \\
(1562)\end{array}$ \\
\hline SŠ s maturitou & $\begin{array}{c}11 \% \\
(1293)\end{array}$ \\
\hline VŠ & $\begin{array}{c}8 \% \\
(490)\end{array}$ \\
\hline \multicolumn{2}{|l|}{ Věk } \\
\hline do 30 let & $\begin{array}{c}24 \% \\
(640) u ́\end{array}$ \\
\hline 30-44 let & $\begin{array}{c}9 \% \\
(1222)\end{array}$ \\
\hline 45 a více let & $\begin{array}{c}6 \% \\
(2011)\end{array}$ \\
\hline \multicolumn{2}{|c|}{ Počet dětí (žádné je ref. kategorie) } \\
\hline Žádné & $\begin{array}{c}46 \% \\
(343)\end{array}$ \\
\hline Jedno & $\begin{array}{c}9 \% \\
(757)\end{array}$ \\
\hline Dvě a více & $\begin{array}{c}6 \% \\
(2773)\end{array}$ \\
\hline
\end{tabular}

\section{Literatura}

AXINN, William G. ; THORNTON, Arland. Mothers, Children, and Cohabitation : the intergenerational Effects of Attitudes and Behavior. American Sociological Review, 1993, roč. 53, s. 233 - 246. ISSN 0003-1224.

BRINES, Julie ; JOYNER Kara. The Ties That Bind: Principles of Cohesion in Cohabitation and Marriage. American Sociological Review, 1993, roč. 53, s. 333 - 355. ISSN 0003-1224.

BROWN, Susan L. ; BOOTH, Alan. Cohabitation versus Marriage : A Comparison of Relational Quality. Journal of Marriage and Family, 1996. roč. 58, s. 668 - 678. ISSN 0022-2445. 
BUMPASS, Larry L. ; Lu, Hsien H. Trends in Cohabitation and Implications for Children's Family Contexts in the United States. Population Studies, 2000, č. 54, s. 29 - 41. ISSN 1381-3579.

CLARKBERG, Martin E. ; STOLZENBERG, Ross M. ; WAITE, Linda J. Attitudes, Values, and the Entrance into Cohabitational Unions. Social Forces, 1995, č. 74, s. 609 - 634. ISSN 0037-7732.

GUPTA, Sanjiv. The Effects of Transitions in Marital Status on Men's Performance of Housework. Journal of Marriage and Family, 1999, roč. 61, s. 700 - 711. ISSN 0022-2445.

HAMPLOVÁ, Dana. Marriage and Cohabitation : Qualitative Differences in Partnership Arrangements. Sociologickýčasopis/Czech Sociological Review, 2002, roč. 38, č. 6, s. 771 - 788. ISSN 0038-0288.

HAMPLOVÁ, Dana. Životní spokojenost, štěstí a rodinný stav v 21 evropských zemích. Sociologický časopis/Czech Sociological Review, 2006, roč. 42, č. 1, s. 35 - 55. ISSN 0038-0288.

HAMPLOVÁ, D. Educational Homogamy among Married and Unmarried Couples in Europe: Does Context Matter? Journal of Family Issues, 2009, roč. 30. č. 1, s. 28 - 52. ISSN 0192-513X.

HEIMDAL, Kristen R. ; HOUSEKNECHT, Sharon K. Cohabiting and Married Couple's Income Organization : Approaches in Sweden and the United States. Journal of Marriage and the Family, 2003, roč. 65 , s. 525 - 538. ISSN 0022-2445.

CHALOUPKOVÁ, Jana. Dohromady nebo každý zvlášt'? Hospodaření s př́ijmy manželských a nesezdaných párů. Sociologický časopis/Czech Sociological Review, 2006, roč. 42, č. 5, s. 971 - 986. ISSN 0038-0288.

KENNEDY, Sheela ; BUMPASS, Larry L. Cohabitation and children's living arrangements New estimates from the United States. Demographic Research, 2008, roč. 19, s. 1663 - 1692. ISSN $1435-9871$.

KENNEY, Catherine. Cohabiting Couple, Filing Jointly? Resource Pooling and U.S. Poverty Policies. Family Relations, 2004, roč. 53, č. 2, s. 237 - 247. ISSN 0197-6664.

KIERNAN, Kathrin L. Partnership Behaviour in Europe : Recent Trends and Issues. In COLEMAN, D. (ed.) Europe's Population in the 1990s. Oxford : Oxford University Press, 1996, s. $63-91$. ISBN 0-198-28894-8.

KREIDL, Martin ; HREŠANOVÁ, Ema. Vzestup mimomanželské plodnosti a mezigenerační přenos sociálního statusu prostřednictvím porodní váhy. In MAREŠ, P., HOFÍREK, O. (eds.) Sociální reprodukce a integrace : Ideály a meze. 1. vyd. Brno : Masarykova univerzita, 2007, s. 153 - 170. ISBN 978-80-210-4439-5.

LANDALE, Nancy S. ; FENNELLY, Katherine. Informal Unions among Mainland Puerto Ricans: Cohabitation o rand Alternative to Legal Marriage. Journal of Marriage and the Family, 1992, roč. 54, s. 269 - 280. ISSN 0022-2445.

LONG, J. Scott ; FREESE, Jeremy. Regression Models for Categorical Dependent Variables Using Stata. 2. vyd. College Station : StataPress, 2006. 527 s. ISBN 978-1-59718-011-5.

LYE, Diane N. ; WALDRON, Ingrid. Attitudes Toward Cohabitation, Family and Gender Roles: Relationships to Values and Political Ideology. Sociological Perspectives, 1997, roč. 40, s. $201-228$. ISSN 0731-1214.

MANNIG, Wendy D. Cohabitation, Marriage, and Entry into Motherhood. Journal of Marriage and the Family, 1995, roč. 57, s. 191 - 200. ISSN 0022-2445.

MANNIG, Wendy D. ; LICHTER, Daniel. Parental Cohabitation and Children's Economic Well-being. Journal of Marriage and Family, 1999, roč. 58, s. 998 - 1010. ISSN 0022-2445.

NOCK, Steven L. A comparison of marriages and cohabiting relationships. Journal of Family Issues, 1995, roč. 16, s. 53 - 76. ISSN 0192-513X.

RINDFUSS, Ronald R. ; VANDENHEUVEL, Audrey. Cohabitation : A Precursor to Marriage or an Alternative to Being Single? Population and Development Review, 1990, roč. 16, s. 703 - 726. ISSN 1728-4457. 
RYDER, Norman B. The cohort as a concept in the study of social change. American Sociological Review, 1965, roč. 30, s. 843 - 861. ISSN 0003-1224.

SELTZER, Judith A. Families Formed outside of Marriage. Journal of Marriage and the Family, 2000, roč. 62, s. 1247 - 1268. ISSN 0022-2445.

SELTZER, Judith A. Cohabitation in the United States and Britain : Demography, Kinship, and the Future. Journal of Marriage and the Family, 2004, roč. 66, s. 921 - 928. ISSN 0022-2445.

SMOCK, Pamela J. Cohabitation in the United States : An Appraisal of Research THemes, Findings, and Implications. Annual Review of Sociology, 2000, roč. 26, s. 1 - 20. ISSN 0360-0572.

SPILERMAN, Seymor ; GERRATANA, Emanuele. Models and Theories in Sociology. In GELMAN, A., CORTINA, J. (eds.) A Quantitative Tour of The Social Sciences. Cambridge : Cambridge Univ. Press, 2009, s. 155 - 163. ISBN 978-0-521-86198-4.

STINCHCOMBE, Arthur L. Constructing Social Theories. New York : Harcourt and Brace, 1968.

THORNTON, Arland ; AXINN William G. ; HILL Daniel H. Reciprocal Effects of Religiosity, Cohabitation, and Marriage. American Journal of Sociology, 1992, roč. 98, s. 628 - 651. ISSN 0002-9602.

THORNTON, Arland ; AXINN, William G. ; XIE, Yu. Marriage and Cohabitation. Chicago : University of Chicago Press, 2007. 373 s. ISBN 978-0-226-79866-0.

\section{Autor}

působí od roku 2010 na Katedře sociologie a na Institutu pro výzkum integrace a reprodukce společnosti (IVRIS) na Fakultě sociálních studií MU. Vyučuje metody sociologického výzkumu, vícerozměrnou analýzu dat a sociální stratifikaci. Výzkumně se orientuje na oblast populačních studií, rodinu a stratifikaci.

Kontakt: kreidlm@fss.muni.cz 